\title{
PRODUCTION COST AND WATER SAVINGS OF PADDY PRODUCED BY DRIP IRRIGATION
}

\author{
Ismail Tas ${ }^{1, *}$ \\ ${ }^{1}$ Canakkale Onsekiz Mart University, Agriculture Faculty, Department of Irrigation Engineering 17020 Terzioglu \\ Campus Canakkale, Turkey
}

\begin{abstract}
Although there are different opinions on climate variability and global warming, it is a common idea in all hypotheses that water will become even more scarce. The water used in the production of paddy, which is one of the most important food sources for the majority of the population in the world, is too much due to the irrigation method. The average global water footprint of paddy production is reported as 1.391 billion $\mathrm{m}^{3} /$ year. Considering this amount, it can be seen that paddy has an enormous environmental footprint. Excessive water use causes both waste of scarce resource water and numerous environmental problems during production. The most important reason for flooded production is the ability of paddy to grow/develop in water and to have a less competitive capacity with weeds. However, when rice is grown with drip irrigation, which is one of the irrigation methods that save water with high efficiency, significant increases in both yield and quality occur. Studies are showing that 50-74.6\% water saving is achieved in paddy production with drip irrigation depending on the region, climate, soil, variety, producer habits, and similar situations. In addition, the cost of one kilogram of paddy produced in the drip irrigation system in the conditions of Canakkale province of Turkey has been calculated as $0.35 \$$. This value has been calculated as $0.44 \$$ in the flooded method. In addition, methane, carbon dioxide, and Nitrous oxide emissions are significantly reduced due to the transition from anaerobic to aerobic conditions. In this way, greenhouse gas emissions, other environmental negative effects, and especially groundwater pollution caused by paddy production can be reduced.
\end{abstract}

Keywords: Flood production, micro-irrigation production, water productivity

\section{INTRODUCTION}

Paddy, the third most-produced grain after corn (1116.34 million metric tons) and wheat (764.49 million metric tons), produced 496.40 million metric tons in 2020. Therefore, it is one of the most consumed grains and is a basic food item for many countries. $90 \%$ of the rice production in the world takes place in Asia. Table 1 shows the countries producing paddy in the world and their production amounts. According to 2018 figures, $67 \%$ of the total paddy production in the world was made by China, India, Indonesia, and Bangladesh (FAO, 2020). In 27 European Union (EU) member countries, the total paddy cultivation area is approximately 450000 ha, the average annual production is approximately 3.1 million tons of paddy and the average annual rice import is approximately 1.1 million tons. The self-sufficiency of the EU in rice is about $70 \%$. Approximately $80 \%$ of EU rice production is carried out from Italy and Spain, and $12 \%$ in Greece and Portugal (Anonymous, 2021a). 
Current Trends in Natural Sciences

Vol. 10, Issue 19, pp. 151-165, 2021

https://doi.org/10.47068/ctns.2021.v10i19.020

Current Trends in Natural Sciences (on-line)

ISSN: 2284-953X

Current Trends in Natural Sciences (CD-Rom)

ISSN: 2284-9521

ISSN-L: 2284-9521

ISSN-L: 2284-9521

Table 1 Rice Producers in the world (x10 ${ }^{3}$ tons)

\begin{tabular}{|l|c|l|c|l|c|l|c|}
\hline Country & Values & Country & Values & Country & Values & Country & Values \\
\hline China & 148300 & Mali & 2150 & Ghana & 575 & Guinea-Bissau & 121 \\
\hline India & 120000 & Laos & 2 & Kazakhstan & 350 & Chile & 111 \\
\hline Bangladesh & 35300 & Iran & 2 & Bolivia & 345 & CostaRica & 95 \\
\hline Indonesia & 34900 & European Union & 1975 & Afghanistan & 343 & Ethiopia & 91 \\
\hline Vietnam & 27100 & Colombia & 1900 & Mozambique & 299 & Togo & 91 \\
\hline Thailand & 18600 & Malaysia & 1825 & Nicaragua & 272 & Turkmenistan & 85 \\
\hline Burma & 12900 & Guinea & 1716 & Iraq & 266 & Kenya & 80 \\
\hline Philippines & 12 & Coted'Ivoire & 1400 & Burkina & 260 & Niger & 75 \\
\hline Japan & 7620 & North Korea & 1360 & Cuba & 255 & Haiti & 70 \\
\hline Pakistan & 7600 & Taiwan & 1225 & Congo (Kinshasa) & 252 & Honduras & 59 \\
\hline Brazil & 7480 & Uruguay & 879 & Cameroon & 230 & Morocco & 42 \\
\hline United States & 7226 & Ecuador & 873 & Mauritania & 225 & Angola & 38 \\
\hline Cambodia & 5840 & Argentina & 819 & Panama & 193 & Ukraine & 38 \\
\hline Nigeria & 5040 & SierraLeone & 819 & Mexico & 193 & Gambia & 18 \\
\hline Egypt & 4 & Senegal & 789 & Suriname & 183 & Guatemala & 18 \\
\hline Nepal & 3696 & Russia & 741 & Benin & 179 & Elsalvador & 16 \\
\hline South Korea & 3507 & Guyana & 712 & Liberia & 170 & Azerbaijan & 8 \\
\hline Srilanka & 3038 & Paraguay & 670 & Uganda & 166 & Brunei & 1 \\
\hline Madagascar & 2560 & $\begin{array}{l}\text { Dominican } \\
\text { Republic }\end{array}$ & 650 & Chad & 156 & Somalia & 1 \\
\hline Tanzania & 2310 & Australia & 605 & Uzbekistan & 150 & Trinidadand Tobago & 1 \\
\hline Peru & 2200 & Turkey & 591 & Venezuela & 130 & & \\
\hline
\end{tabular}

According to the United Nations-backed Sustainable Rice Platform, rice is the main food source for more than half of the global population. $30-40 \%$ of the volume of clean water in the world is used in paddy production. The demand for rice is expected to increase by $25 \%$ by 2050 . Experts agree that paddy production should become more sustainable (Anonymous, 2021b).

Paddy production is produced in two ways: aerobic and anaerobic production. Anaerobic production (also called conventional production) is a production method made by the flood method. The oldest and most used method used in production in the world is the flood method. The most important reason for the adoption of this method is the ability of paddy to develop in the water beside and the weak competition with weeds. Increasing knowledge and technological developments in crop production have made it possible to produce paddy by the anaerobic method. In recent years, studies on the surface and subsurface drip irrigation and paddy production have increased. In addition, sprinkler irrigation method (a study comparing pivot and linear system) and sub-irrigation method (which applied by raising the groundwater are also available) have been using for production.

Approximately $34-43 \%$ of irrigation water in the world is used in paddy production. Approximately $75 \%$ of the production is produced by the method of flooded (Maraseni et al., 2018; Arbat et al., 2020). The total amount of irrigation water used in flooded production varies between 6750-44500 $\mathrm{m}^{3} /$ ha depending on the soil texture/type, paddy type, climate conditions, paddy production culture and water application method (Maclean et al., 2013; Arbat et al., 2020). In other studies, it is reported that the seasonal irrigation water requirement of paddy varies between 1650-3000 mm (Tuong and Bouman 2003, Lampayan and Bouman 2005). In Turkey, it is reported in different studies (Ozkara 1981, Ayday et al. 1981, Cakir et al. 1998, Anonymous 2009, Tuna 2012; Ozer, 2018) that the seasonal irrigation water need varies between $788-4355 \mathrm{~mm}$. 
In paddy, besides irrigation water quality, another effective factor is irrigation water temperature. The appropriate irrigation water temperature is between $22-30{ }^{\circ} \mathrm{C}$. A decrease in water temperature below $15{ }^{\circ} \mathrm{C}$ causes decreased inefficiency (Tulucu, 2003). Zia et al. (1994) studied the effect of irrigation water at 17 and $21{ }^{\circ} \mathrm{C}$ in paddy production for 30 days. As a result of the research, it was concluded that low levels of irrigation water temperature decreased the plant's nitrogen, phosphorus, and potassium intake from the soil, thus causing a decrease in plant development (Ozer, 2018).

The global average water footprint of paddy production is estimated at 784 billion $\mathrm{m}^{3}$ year $^{-1}(48 \%$ green $=$ rainwater, $44 \%$ blue $=$ surface water, and $8 \%$ gray $=$ nitrogen fertilized water). The volume of water that seeps deep in the paddy fields and the moisture remaining in the soil after harvest is equal to 607 billion $\mathrm{m}^{3}$ year $^{-1}$. The total use of blue water used in paddy production including deep infiltration is 636 billion $\mathrm{m}^{3} /$ year. Adding the total water footprint and the volume of deep infiltration, the global water use of paddy production is calculated as 1.391 billion $\mathrm{m}^{3}$ year (Chapagain and Hoekstra, 2010).

Considering the current century and the future situation, it is known that water will become more scarce day by day. In parallel with the developing technology and the increase in the water demand, in the last few decades, there has been a transition to the production method with micro-irrigation methods instead of the traditional paddy production model. Especially the drip irrigation method, its use with the right operating methods, provides a serious water saving as well as high efficiency and quality. However, studies on paddy production with drip irrigation are limited. The irrigation water required for paddy production is getting more and more difficult day by day. It is both essential and vital to use water-saving irrigation techniques to maintain efficiency and quality, especially to provide the needed irrigation water. The use of modern irrigation methods instead of conventional production (flooded) allows large amounts of irrigation water to be saved, as well as increases in efficiency and quality in many varieties. In some studies currently carried out, it is stated that large amounts of water savings have been achieved, especially in production with drip irrigation. For example, Bouman et al. (2006) reported that yields varying between 1205-5664 $\mathrm{kg} \mathrm{ha}^{-1}$ were obtained against 5470-6440 $\mathrm{m}^{3} \mathrm{ha}^{-1}$ irrigation water. In recent years, Luo et al. (2019) reported that in addition to yield and grain quality, intensive studies are carried out to develop new paddy varieties with high drought resistance.

Paddy (Oryza sativa L.) is the most stable food product in the world and Asia, and more than two billion people get $60-70 \%$ of their food energy from rice and its derivatives. Recently, paddy cultivation is under serious threat mainly due to factors such as water availability, extreme weather events, soil health deterioration, and climate change. Due to the increasing water scarcity, it is vital to develop alternative paddy rice production methods that require less water. One of the methods that save a significant amount of water in paddy production is drip irrigation. Using drip irrigation, aerobic production of traditional paddy rice production system, especially in areas where irrigation water is insufficient, will be beneficial in reducing the pressure on all water resources. Drip irrigation is a tool that can reduce the irrigation water requirement and increase efficiency at the same time. In many studies in which field crops are irrigated with drip irrigation method, it has been determined that this method is beneficial in reducing water use, homogeneous application of water and nutrients, increased input use efficiency as well as increased productivity and economic returns (Wassmann et al., 2000; Ramesh et al., 2019).

In a study conducted for the future of paddy rice production, which consumes the lion's share (85\%) of water used in irrigated agriculture, technological applications that will use less water and their 
development and adoption were made. Paddy is generally grown in conditions that require large volumes of water and that the water supply is sufficient in terms of quality and canteen. A demonstration for farmers was conducted in the Indian state of Haryana to increase the access/use of micro-irrigation technologies among farmers. Water savings of $42 \%$ were achieved in drip irrigation, while an increase in efficiency of $11.65 \%$ was achieved. Rice is the main grain for India and South Asian countries. According to the literature, although the total irrigation water need per season is reported to be $1200-1400 \mathrm{~mm}$, farmers use much more water (up to $2000 \mathrm{~mm}$ ) in many regions (Sharma et al., 2018).

Drip irrigation provides substantial savings from irrigation water, fertilizer, pesticide/herbicide and labor costs as well as soil cultivation, planting, maintenance, harvesting, field rent and other costs. The most important problems in paddy production with drip irrigation are weed control and initial investment cost. Today, these problems have been resolved in most of the world. There have been great developments in both herbicide and pesticide development and in the plastic industry. Therefore, there are many different alternatives both in agricultural struggle and in solving problems with finance. In addition, under conditions where the drip irrigation system is used, it is possible to prevent/reduce soil-borne diseases in the plant root region. Taha (2020) reports that the drip irrigation method is beneficial in reducing/eliminating the effects of nematodes that cause significant damage to plants.

In the surface drip irrigation system (DI), since the lateral pipes are located on the soil surface, they cause problems in the passage of the machines, as well as all the lateral lines, are collected until the next season. Such problems are not encountered in subsurface drip irrigation (SDI). As is known, drip irrigation pipes are laid under the soil surface and can be used for a very long time (up to 20 years). One of the most important issues in SDI systems is the laying depth of lateral pipes. The lateral laying depth is very important especially for the germination and development of shallowrooted plants.

Rajwade et al. (2018) study the use of SDI in paddy rice production. Lateral ranges of 0.4 and 0.6 $\mathrm{m}$, dripper range $0.3 \mathrm{~m}$, and $4 \mathrm{~L} \mathrm{~h}^{-1}$ emitter flow rate were selected. At the end of the study, significant differences occurred in both lateral spacing, grain yield, water and $\mathrm{N}$ utilization efficiency. According to traditional production conditions, yields are similar under the condition that the lateral spacing of SDI is $0.60 \mathrm{~m}$, while saving $25-50 \%$ from nitrogen. In addition, an increase in Water Productivity $\left(\mathrm{WP}=0.23-0.61 \mathrm{~kg} \mathrm{~m}^{-3}\right)$ has been determined. Parthasarathi et al. (2015) stated that the lateral depth of $0.15 \mathrm{~m}$ and the dripper range of $0.30 \mathrm{~m}$ was the best choice. In this study, three different lateral spacing $(0.6,0.8$, and $1.0 \mathrm{~m})$ and two different dripper flow rates $(6$ and $1.0 \mathrm{~L} \mathrm{~h}^{-1}$ ) were examined. Both studies concluded that although WP was increased, the throughput of SDI was slightly reduced compared to conventional production. However, in conditions with $0.8 \mathrm{~m}$ lateral spacing and $1 \mathrm{~L} \mathrm{~h}^{-1}$ emitter flow, $30 \%$ more water savings, improvement in root properties (higher root length, RMD, root biomass and root volume) improves yield and WP values.

Global warming is an important issue for people. One of the most important causes of global warming is the increase in the concentration of greenhouse gases, namely carbon dioxide $\left(\mathrm{CO}_{2}\right)$, methane $\left(\mathrm{CH}_{4}\right)$ and nitrous oxide $\left(\mathrm{N}_{2} \mathrm{O}\right)$ in the atmosphere. Approximately $11 \%$ of total global methane emissions to the atmosphere come from flooded rice production in India (Moran and Pratt, 2010; Ramesh et al., 2019). Field studies show that if there is a difference in applications such as water, fertilizers and pesticides in paddy production, it will have a significant effect on greenhouse gas emissions resulting from production (Wassmann et al., 2000; Ramesh et al., 2019). 
He et al. (2013) obtained a yield of $5785 \mathrm{~kg} \mathrm{ha}^{-1}$ against $11215 \mathrm{~m}^{3} \mathrm{ha}^{-1}$ irrigation water with surface drip irrigation (DI) method with NingGeng28 variety. The yield obtained was lower than that of conventional production (8300 $\left.\mathrm{kg} \mathrm{ha}^{-1}\right)$. In addition, water productivity (WP) in DI was obtained as $0.52 \mathrm{~kg} \mathrm{~m}^{-3}$, twice the conventional production. Parthasarathi et al. (2015), in the production of paddy irrigated with DI irrigation (ADT (R) 45 varieties yielded an average of $4834 \mathrm{~kg} \mathrm{ha}^{-1}$ ) in India, the WP value calculated by including the contribution of falling rainfall in the irrigation season was determined as $0.84 \mathrm{~kg} \mathrm{~m}^{-3}$. Similarly, in the Baldo variety, Arbat et al. (2018) obtained $5565 \mathrm{~kg} \mathrm{ha}^{-1}$ yield and $0.60 \mathrm{~kg} \mathrm{~m}^{-3} \mathrm{WP}$.

Beser et al. (2015), in their study, grew paddy by drip irrigation. After two years of study, they determined the average evapotranspiration value as $789 \mathrm{~mm}$. Among the varieties used in the study, the highest yield was determined in Duragan $\left(6517 \mathrm{~kg} \mathrm{ha}^{-1}\right)$, followed by Osmancik-97 (6238 kg ha$\left.{ }^{1}\right)$ and Halilbey $\left(6231 \mathrm{~kg} \mathrm{ha}^{-1}\right)$ and these varieties were suggested as varieties that can be used in production with drip irrigation. At the same time, it is reported that these varieties save approximately $50 \%$ more water in drip irrigation conditions compared to flooded irrigation.

Tajane et al. (2016) report that a higher yield is obtained in paddy rice production with a microirrigation system (MIS). In various trials conducted with the drip irrigation method in farmer fields in Tamil Nadu Agriculture University, Andhra Pradesh and Punjab regions of India, up to 30\% increase in yield and $97 \%$ water savings compared to traditional irrigation method were achieved. On the other hand, significant savings were made in seed, fertilizer, pesticide/herbicide and other input costs. This MIS system enables sustainable production and product rotation. In case MIS is used in paddy production; i) ease of cultural operations, ii) increase in the number of siblings, iii) increase in cluster length and number of grains per cluster, iv) increase in grain weight, v) healthy increase in root development, vi) deep infiltration of nutrients is not in the correct operation technique, vii) water-saving, viii) protection of soil health and ix) increasing the land use capacity of the farmers and enabling an increase in total income.

The method of production with flooded rice, which is the basic food source of billions of people, causes serious environmental costs. With another return, there is a serious environmental footprint. Paddy rice production with the flooded method alone provides $12 \%$ of methane emission, which is one of the strongest greenhouse gases, which is shown to cause global climate change (Anonymous, 2021c).

Nitrogen recovery in paddy production systems with basin method is at most 30-40\% (De Datta, 1995). In this method, production is made in clay soils and nitrogen loss is tried to be reduced by deep infiltration. The nitrogen loss caused by the water coming from the basin to the drain can be controlled to a great extent. However, ammonia $\left(\mathrm{NH}_{3}\right)$ evaporation and denitrification processes are considered to be the major nitrogen loss mechanisms affecting the productivity of urea and other $\mathrm{N}$ fertilizers (De Datta, 1995). In general, a much higher proportion of fertilizers is applied in the production method where the lake method is used, compared to the precipitation-based production system. For example, while 22\% of the fertilizers used in India in the 2003-2004 period were used in paddy produced by lapping method, $9.6 \%$ were used in rain. This situation is higher in Indonesia, with $52 \%$ of the total fertilizer used in paddy production (FAO, 2005). The global loss of $\mathrm{NH}_{3}$ to the atmosphere from the use of 12 million tons of mineral fertilizer $(\mathrm{N})$ annually in paddy production with basin method is 2.3 million tons $\mathrm{N}$ year ${ }^{-1}$ or $20 \%$ of the $\mathrm{N}$ application. $97 \%$ of this fertilization is done by developing countries (FAO and IFA, 2001). In the basin method, the loss with denitrification is around $10 \%$. This rate increases up to $40 \%$ in the intermittent lagoon system 
(Fillery and Vlek, 1982). According to Xing and Zhu (2000), nitrogen loss with deep infiltration is around 5\%. The rate of runoff to drainage varies between 10-30\% (Chapagain and Hoekstra, 2010). In a study comparing drip irrigation and basin irrigation methods in paddy, no clear difference was determined in terms of $\mathrm{N}_{2} \mathrm{O}$ emission during the seedling period. However, the amount of $\mathrm{N}_{2} \mathrm{O}$ released into the atmosphere during both flowering $\left(2.3 \mathrm{mg} \mathrm{m}^{-2}\right.$ day $\left.^{-1}\right)$ and maturity stage $(2.9 \mathrm{mg}$ $\mathrm{m}^{-2}$ day $\left.^{-1}\right)$ under flooded irrigation conditions is considerably higher compared to drip irrigation $(0.5$ $\mathrm{mg} \mathrm{m}^{-2}$ day $^{-1}$ in both stages). was found high. In addition, when compared in terms of methane gas release, lagoon irrigation (Tillering: 9.31, Panicle initiation: 8.33, Flowering: 6.4 and Maturity: 4.7 $\mathrm{mg} \mathrm{m}^{-2}$ day $^{-1}$ ), drip irrigation (Tillering: 5.17, Panicle initiation: 2.5, Flowering: 1.6 and Maturity: $1.5 \mathrm{mg} \mathrm{m}^{-2}$ day $^{-1}$ ), it has been determined that it has a very high emission in terms of methane gas emission. The total amount of irrigation water used in flood irrigation was $1931 \mathrm{~mm}$, WP was 2.69 and thousand-grain weight was $16.40 \mathrm{~g}$. These values were determined as $1317 \mathrm{~mm}, 3.01$ and 16.95 $\mathrm{g}$ in drip irrigation. Water savings of $30 \%$ on average have been achieved. In addition, it can be said that the use of efficient fertilizers positively affects the reduction of greenhouse gas emissions, since paddy production with drip irrigation is completely flooded production (Ramesh et al., 2019).

$\mathrm{Li}$ (2012) compared the emission of methane gas $\left(\mathrm{CH}_{4}\right)$ with conventional production in a watersaving method. In water-saving applications, methane emission was found $39-85 \%$ less than applications with flood irrigation. They also pointed out that there is no decrease in efficiency in water-saving methods. In the same direction; Peng et al. (2010) reported that methane gas emission could be reduced by $73.2-85 \%$ with controlled irrigation practices.

In this study, the production cost of paddy produced with drip irrigation and flooded irrigation was calculated for Canakkale. In addition, with the studies on paddy production with drip irrigation, the comparison of the total yield, the amount of irrigation water applied, the irrigation water-saving rate and the water use efficiency (WUE) parameters of the traditional (flood) production were made.

\section{MATERIALS AND METHODS}

\subsection{Land Features}

Canakkale is connected to the Eastern Thrace lands of the Balkan Peninsula, which falls in the northwest direction of Turkey. It has landed on the Gallipoli Peninsula and the Biga peninsula, which is an extension of Anatolia. It was established on an area of $993318 \mathrm{~km}^{2}$ between $25-35$ and 27-45 east longitudes and 39-30 and 40-45 north latitudes It is surrounded by Balikesir province in the east and southeast direction, the Aegean Sea in the west, Edirne province in the northwest, Tekirdag province and the Marmara Sea in the north.

It has a total area of 993318 ha. However, 33.4\% (331633 ha) of it is processable. This value consists of 252747 ha of fields, 32573 ha of olive groves, 20942 ha of vegetables, 20754 ha of orchards, and 4617 hectares of vineyards. While irrigated agriculture is done in $25 \%$ of the total agricultural lands in Canakkale, this rate is $19.5 \%$ in Turkey. While irrigated agriculture is done in $73 \%$ of the irrigable areas in the province, the same rate is $65 \%$ in Turkey. The amount of paddy produced in Canakkale province corresponds to $9.59 \%$ of Turkey's total production.

\subsection{Cost Calculation in Production}

Tillage and Planting: In anaerobic production, a tractor with high traction power is needed for soil preparation (laser leveling device, leveling shovel, embankment plow) and other processes. Accurate ground leveling is very important to achieve a high degree of uniformity and efficiency. Many basins are so small that precision equipment cannot work effectively. The surrounding dikes must be well maintained to avoid damage and waste, and for the basin, the dikes must be higher 
than other surface irrigation methods. To achieve the maximum level of efficiency, the flow rate per unit width must be as high as possible without causing soil erosion. When designing irrigation projects for small watersheds or furrows and boundaries, the ability to control and export structures may not be sufficient to improve the watershed. In the flood irrigation method, the preparation of the field for planting from November to the end of April, tillage, duplication, preparation of basin, leveling and embankments are time-consuming, as well as the need for a serious workforce and consequently high costs. In addition, a mistake made during the construction of the banks may cause the walls to collapse with the effect of the wind after the water is filled in the basins. When evaluated in terms of sowing and the amount of seed used, the basins should be filled with water first in the basin irrigation method. Then, the seed should be soaked 1-2 days in advance and seed planting should be done by calculating the wind load and direction with a qualified worker or tractors with iron tires. An effective wind during planting may cause the seed to collect in certain areas. This is taken into consideration during the transplantation process.

Maintenance Works: When evaluated in terms of labor force need; In paddy cultivation with basin irrigation, a qualified workforce varying between 22-26.50 \$/day (for 2020) is needed for irrigation. Harvest: In the irrigation method, harvesting can be made at least 10 to 15 days after the water is cut. A tracked combine harvester is needed for harvesting. Harvesting of paddy by flood production is more difficult than the drip irrigation method and work efficiency is low. In both methods, harvesting is done with a rented combine harvester. In the drip irrigation method, harvest can be made 5 to 7 days after the water is cut. There is no need for a crawler harvester for harvesting. The work efficiency of the combine is higher. The combined harvester rent in drip irrigation is lower than the harvest in the basin method.

Inputs: When evaluated in terms of chemical fertilizers and pesticides used; It has been declared by the producers that there is not much difference in the amount and types of chemical fertilizers and pesticides used in both irrigation methods.

Field Rent: In the irrigation method, the slope of the land is not required to exceed $1-2 \%$. In other words, the parcels where paddy is produced are flat and heavy textured soils with a low infiltration rate. For this reason, the field rental fee is higher since the base lands are preferred. However, by using the drip irrigation method, sloping lands that the soil structure does not notice can be easily used in paddy cultivation. There is no need for the leveling of the land.

Capital Interest: Total Expenses, TC. Taking into account the crop production loan interest value of Ziraat Bank for that year (12\% for the year 2020), it was used in calculating $6 \%$ over the 6 months for paddy.

General Administration Expenses: It was calculated taking into account 3\% of the total cost.

\section{RESULTS AND DISCUSSIONS}

\section{Production Costs}

In the study, Canakkale, one of the provinces with the highest production in Turkey, has been evaluated by taking reference values as an example. According to TURKSTAT data, Canakkale Province in Turkey's $4^{\text {th }}$ largest producer with 93020 tons of paddy production from an area of 11023.6 ha in 2019. According to the data of Canakkale Provincial Directorate of Agriculture and Forestry, the average yield is $8900 \mathrm{~kg} \mathrm{ha}^{-1}$ and the production cost of 1 kilogram of paddy is $0.44 \$$ in the flooded irrigation method, while this value is $0.35 \$$ in the drip irrigation method. The basic parameters and values taken into account in the calculations are presented in Table 2. 
According to the calculations made, the application of the drip irrigation method in paddy cultivation saves approximately $60 \%$ in tillage and sowing operations, $70 \%$ in labor and $30 \%$ in field rent compared to the irrigation method of lake irrigation. It increases other production inputs by $2 \%$. When evaluated in general, the application of drip irrigation in paddy cultivation reduces the cost by approximately $20 \%$ compared to the irrigation method of the basin.

Soman (2012) determined that the payback period of drip irrigation varies between 1.23-2.09 seasons in different regions of India. Also, the benefit/cost ratio is calculated between 1.4-2.1. Sharma et al. (2018) reported in their study that drip irrigation provided $42 \%$ water savings, $11.7 \%$ increase in yield and $13.7 \%$ increase in income. Parthasarathi et al. (2018) achieved 49.7\% water savings in surface and subsurface drip irrigation methods in their study. Water productivity was determined as $0.99 \mathrm{~kg} \mathrm{l}^{-1}$ in the subsurface drip irrigation system, $0.94 \mathrm{~kg} \mathrm{l}^{-1}$ in the surface drip irrigation method, and $0.49 \mathrm{~kg} \mathrm{l}^{-1}$ in conventional flooded irrigation in the aerobic rice production system method. The yield rate is reported to have increased by $22.4 \%$ in SDI and $19.1 \%$ in DI.

Table 2. Comparison of the Cost of Drip Irrigation and Flood Irrigation Methods in Paddy Production

\begin{tabular}{|l|c|c|c|}
\hline \multicolumn{1}{|c|}{ Parameter } & $\begin{array}{c}\text { Flooded } \\
(\$)\end{array}$ & $\begin{array}{c}\text { Drip } \\
(\$)\end{array}$ & $\begin{array}{c}\text { Difference } \\
(\%)\end{array}$ \\
\hline Tillage and Planting & 53.79 & 22.57 & 58 \\
\hline Maintenance Works & 31.75 & 9.52 & 70 \\
\hline Harvest & 35.27 & 35.27 & 0 \\
\hline Inputs & 162.43 & 164.90 & -2 \\
\hline Field Rent & 61.73 & 44.09 & 29 \\
\hline Capital Interest & 27.51 & 22.05 & 20 \\
\hline General Administration Expenses & 10.23 & 8.29 & 19 \\
\hline Total & 382.72 & 306.70 & 20 \\
\hline
\end{tabular}

In aerobic production, the equipment used in normal grain production is sufficient and the required pulling power is reduced. In addition, depending on this situation, the fuel need is also saved. When evaluated in terms of soil preparation before planting; In paddy cultivation with drip irrigation method, in soil preparation for sowing, $2^{\text {nd }}$ class soil cultivation tools are used as goble, cultivator, soil mill, harrow and so on. With such tools, the field can be made ready for planting in a very short time such as 8-10 days. For soil preparation, compared to the flood irrigation method, drip irrigation can save about $60 \%$ in the costs for preparing the soil for planting. In addition, there is no need for qualified workforce since the planting is done with a grain drill. Considering the amount of seed used, both methods generally use the same amount of seed.

In the drip irrigation method, there is no need for any labor force for irrigation. Manpower is needed only in the stage of installation of irrigation system on the land and collecting it at the end of production. As mentioned before, a qualified workforce and equipment are required for seed sowing, spraying and fertilization in the flood irrigation method. In the drip irrigation method, fertilizers and pesticides can be given to the root area of the plant through drippers with very little labor. Drip irrigation can save $70 \%$ at cost of labor work.

If legume forage is planted as a pre-plant in cultivation using the drip irrigation method, the use of nitrogenous fertilizer can be slightly reduced and an increase in the development, yield and quality of the paddy plant is observed in such cultivation. The drip irrigation method allows the application of pesticide/herbicide and fertilizer in the root area of the plant and very easily without the use of any labor work and equipment until harvest time. Yield and quality can be increased by those applications. Since too much water is used in the flood irrigation method, evaporation, 
denitrification and deep percolation are increased using fertilizers. This situation also causes groundwater pollution. According to Topcu and Tas (2020), groundwater of Biga plain in Canakkale was contaminated by the use of nitrogen fertilizers in paddy cultivation.

When the changes in the soil are examined, the structure and biological balance deteriorate due to anaerobic conditions in the irrigation method of the flood. In micro-irrigation methods such as drip irrigation, such problems do not occur when there is no groundwater problem. In addition, in the flood irrigation method, groundwater in the plant root zone is formed, a mosquito problem occurs near of the paddy production area and deep groundwater can be polluted by nitrate and other fertilizers. In this respect, serious public health problems arise. In this case, there is additional spraying for mosquitoes and therefore an additional cost in terms of public health to the spraying used for production.

Considering the irrigation system, there is no significant cost in the flood irrigation method. just there are only labor works. However, for the drip irrigation system, which is one of the micro irrigation systems, materials such as laterals, manifolds and main pipelines, fittings and control units are needed. The economic life of system components are around 25 years (except laterals).

In the field rent, production of paddy by drip irrigation can be done on all kinds of lands, so the field rental fee is lower. There is $30 \%$ saving in the field rental in micro irrigation systems.

When evaluated in terms of pre-crop and post-harvest second crop cultivation, it is possible to grow a pre-crop in the same field before paddy cultivation under the drip irrigation method. It is possible to grow especially grain and legume group feed crops (such as barley, rye, oats, ryegrass vetch, feed peas). In addition, when leguminous fodder crops are grown as a pre-plant, some savings are got from the nitrogen fertilizer used due to the nitrogen fixation it provides to the soil (a decrease in the amount of nitrogen fertilizer to be used in production), and groundwater/groundwater pollution due to paddy production is also reduced. Under conditions where the micro irrigation method is used, a third crop (lettuce, spinach, etc.) can be produced after the paddy harvest. If this production method is applied, more income can be obtained from a unit area. In addition, if the specified rotation is applied, important contributions can be made to weed control.

\section{Irrigation Water and Yield Comparison}

The results obtained in the studies mainly on drip irrigation with traditional production are summarized in Table 3. Serious differences were found between the results of the research. Each study, the research area, climate, soil, irrigation water quality and quantity, genetic characteristics of the selected varieties, differences and timing of fertilizer and pesticide applications, producer habits, cultural processes, the suitability of the practices to the research subject, the suitability of irrigation practices to irrigation method, irrigation time and the application of the amount of irrigation water depending on the selected irrigation method and plant demand, and the experience and knowledge of the researchers in research. The reasons for the differences in Table 3 are thought to be caused by the effects of one or more of these factors. Studies showing that water savings, efficiency and water use efficiency values obtained especially under conditions where micro-irrigation methods are used are lower than traditional production, whether the applied methods are designed according to the technique (especially micro irrigation systems), the operation is not carried out in accordance with the irrigation method and the varieties are not selected. has been determined. In addition, some studies have conducted appropriate system research and may have caused the difference in question. 


\section{Current Trends in Natural Sciences}

Vol. 10, Issue 19, pp. 151-165, 2021

https://doi.org/10.47068/ctns.2021.v10i19.020

Current Trends in Natural Sciences (on-line)

Table 3 Comparison of traditional and micro irrigation system production in terms of water saving and efficiency in paddy

\begin{tabular}{|c|c|c|c|c|c|c|}
\hline References & $\begin{array}{l}\text { Irrigation } \\
\text { methods }\end{array}$ & $\begin{array}{c}\text { Water } \\
\text { Requirement } \\
(\mathrm{mm})\end{array}$ & $\begin{array}{c}\text { Water } \\
\text { Saving }(\%)\end{array}$ & Yield $(\mathrm{kg} / \mathrm{ha})$ & $\begin{array}{l}\text { Increase in } \\
\text { yield (\%) }\end{array}$ & 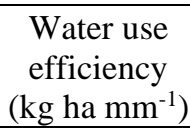 \\
\hline \multirow{2}{*}{$\begin{array}{l}\text { Anonymous, } \\
\text { 2021d }\end{array}$} & Flood & 1200 & & 5200 & & 4.33 \\
\hline & Drip & 619 & 48 & 5940 & 14 & 9.6 \\
\hline \multirow{2}{*}{$\begin{array}{l}\text { Fawibe et al., } \\
2020\end{array}$} & Flood & 1144- 1312 & & 9180 & & 0.47 \\
\hline & Drip & $556-643$ & $48.6-49$ & 9730 & 5.7 & 0.80 \\
\hline \multirow{2}{*}{$\begin{array}{l}\text { Ramesh et al., } \\
2019\end{array}$} & Flood & 1931 & & 5200 & & 2.69 \\
\hline & Drip & 1317 & 31.8 & 4800 & -7.7 & 3.50 \\
\hline \multirow{2}{*}{$\begin{array}{l}\text { Sharma et al., } \\
2018\end{array}$} & Flood & 2000 & & 6153 & & \\
\hline & Drip & 840 & 42 & 6870 & 11.65 & \\
\hline \multirow{2}{*}{$\begin{array}{l}\text { Sarkar et al., } \\
2018\end{array}$} & Flood & 600 & & 2290 & & 1.240 \\
\hline & Drip & 258 & 57 & 3100 & 35.4 & 8.126 \\
\hline \multirow{2}{*}{ Singh et al., 2018} & Flood & & & 5224.50 & & \\
\hline & Drip & & & 8076.25 & 35.31 & \\
\hline \multirow{4}{*}{ Ozer, 2018} & Flood & 1899 & & 7950 & & \\
\hline & AWD & 1281 & 32.5 & 7600 & -4.4 & \\
\hline & Spring & 1237 & 34.9 & 5317 & -33.1 & \\
\hline & Drip & 1217 & 35.9 & 6390 & -19.6 & \\
\hline \multirow{2}{*}{$\begin{array}{l}\text { Parthasarathi et } \\
\text { al., } 2018\end{array}$} & Flood & 829.8 & & 4181 & & 0.37 \\
\hline & Drip+SDI & 647.5 & 22 & 5389 & 28.9 & 0.66 \\
\hline \multirow{2}{*}{$\begin{array}{l}\text { Sharda et al., } \\
2017\end{array}$} & Flood & & & $6273-6846$ & & $0.42-0.52$ \\
\hline & Drip & & & $7340-8010$ & 17 & $0.81-0.88$ \\
\hline \multirow{3}{*}{$\begin{array}{l}\text { Bansal et al., } \\
2018\end{array}$} & Flood & 587.4 & & 6225 & & 10.6 \\
\hline & Spring & 419.0 & 28.7 & 4800 & -22.9 & 11.5 \\
\hline & Drip & 407.3 & 30.7 & 6950 & 11.65 & 17.1 \\
\hline \multirow{2}{*}{$\begin{array}{l}\text { Sharma et al., } \\
2017^{1}\end{array}$} & Flood & $1780-2169$ & & $4100-4200$ & 0.51 & $0.19-0.23$ \\
\hline & Drip & $675-726$ & $33.5-37.9$ & $2100-3010$ & $-(0.51-0.72)$ & $0.28-0.44$ \\
\hline \multirow{2}{*}{$\begin{array}{l}\text { Sharda et al., } \\
2017\end{array}$} & Flood & & & 6273-6846 & & $0.42-0.52$ \\
\hline & Drip & & & $7340-8010$ & 17 & $0.81-0.88$ \\
\hline \multirow{2}{*}{$\begin{array}{l}\text { Shaibu et al., } \\
2015\end{array}$} & Flood & 2693-3847 & & 4920 & & \\
\hline & AWD & 807.9-1923.6 & $30-50$ & 4740 & -3.7 & \\
\hline \multirow{2}{*}{$\begin{array}{l}\text { Rekha et al., } \\
2015\end{array}$} & Drip & $487-846$ & - & $3375-6503$ & & $0.31-0.91$ \\
\hline & & & & & & \\
\hline \multirow{2}{*}{ Rao, 2013} & Flood & 553.3 & & & & \\
\hline & Drip & 291.42 & 52.7 & & & \\
\hline \multirow{2}{*}{ Soman, 2012} & Flood & & & 7660 & & \\
\hline & Drip & & 66.3 & 9390 & 22.5 & \\
\hline \multirow{2}{*}{ Tuna, 2012} & Flood & 4639 & & 8140 & & \\
\hline & Drip & 1446 & & 7110 & -12.7 & \\
\hline \multirow{2}{*}{ Anonim, 2010} & Flood & 1806 & & 8000 & & 0.44 \\
\hline & Drip & 789 & 43.7 & 6900 & -13.8 & 0.88 \\
\hline \multirow{2}{*}{ Atta, 2008} & Flood & 1469 & & 8800 & & \\
\hline & Furrow & 902 & 38.6 & 9300 & 5.7 & \\
\hline \multirow{2}{*}{$\begin{array}{l}\text { Vories et al., } \\
2002\end{array}$} & Flood & $1680-3310$ & & 7040 & & $2.07-4.81$ \\
\hline & Furrow & $630-840$ & $62.5-74.6$ & 6020 & -14.5 & $5.88-10.41$ \\
\hline
\end{tabular}

${ }^{1}$ Complementary irrigation was applied in production based on rainfall and 60.6-111.5 mm irrigation water was applied with drip irrigation in addition to $614 \mathrm{~mm}$ of precipitation, and 1166-1555 $\mathrm{mm}$ irrigation water was applied in basin irrigation.

AWD: Alternate wetting and drying irrigation 
In order to achieve the targeted success in water-saving with efficiency and quality in paddy production, must be done in below; i) irrigation system is designed correctly and applied to the land, ii) good quality of the materials in the irrigation system, iii) choosing the right plant variety, iv) the applications (fertilization, spraying and other cultural processes) should be suitable for the irrigation system.

Under aerobic production conditions, paddy can till 30\% more than flood irrigation system. This means an approximately similar rate of increase in yield. In addition, there is a serious increase in quality. The efficiency of paddy (depending on the varieties) can rise up to $70 \%$. In addition, micro irrigation methods are more advantageous in conditions where low quality irrigation water is used. Plant growth and their penetration into the plant body are at lower levels in conditions of both irrigation water salinity and heavy metal pollution. Anonymous (2021e) reports that under the conditions of paddy production with drip irrigation, the arsenic intake of plants is $90 \%$ less and if only $10 \%$ of the producers produce with this method, the reduction in $\mathrm{CH}_{4}$ emissions will be equivalent to the removal of 40 million cars from the road.

In the Russian Federation, more than 20 thousand $\mathrm{m}^{3}(2000 \mathrm{~mm})$ of irrigation water is used per hectare in the production of paddy by flood method. However, the evapotranspiration value of the plant is around 6-8 thousand $\mathrm{m}^{3}(600-800 \mathrm{~mm})$ (Kruzhilin et al., 2017).

Bouman et al. (2002) stated that aerobic paddy cultivation is a method concept in which new and high-yielding varieties are grown by irrigation and fertilization without flooded production, due to the increase in the amount of water resources today. They stated that new varieties and methods should be developed in order to be successful in this system. For this purpose, in the research they conducted in North China, newly developed aerobic varieties were compared with high-yielding varieties suitable for traditional irrigation. While the highest yield of aerobic rice variety was 4.7$6.6 \mathrm{t} \mathrm{ha}^{-1}$, a yield of 8.0-8.8 $\mathrm{t} \mathrm{ha}^{-1}$ was obtained from high-yielding varieties suitable for traditional irrigation. In aerobic conditions; It is reported that water use is less than $50 \%(470-650 \mathrm{~mm})$, water efficiency is $64-88 \%$ more, and labor requirements are $55 \%$ less than traditional irrigation.

The future of paddy production, which takes the lion's share of water used in agriculture (up to $85 \%$, although it differs by region), will largely depend on the development and adoption of technologies and practices that will use less water. The water productivity of paddy produced by the flooded method is $0.15 \mathrm{~kg} \mathrm{~m}-3$. If drip irrigation is used in paddy production, there is an increase of up to $50 \%$ yield, higher quality clean straw production, $66 \%$ saving from irrigation water, $52 \%$ energy saving in pumping, reduced seed usage and more efficient fertilizer use (Soman, 2012).

\section{CONCLUSIONS}

Precise application of water along with constant wetting techniques would be achievable under drip irrigation (Hanson and May, 2007). In addition, drip irrigation generally results in good crop development by limiting soil evaporation and deep percolation. Moreover, fertigation can improve the yield potential of rice by applying split doses of fertilizers precisely at the right time in the right place (Adekoya et al., 2014). Also, the physiology of the crop was significantly influenced by drip irrigation (Tognetti et al., 2003) with enhanced water, nutrients (Eid et al., 2013) and resource use efficiency (Rajwade et al., 2018; Parthasarathi et al., 2018).

With aerobic paddy production, low greenhouse gas emissions $\left(\mathrm{CH}_{4}, \mathrm{CO}_{2}\right.$ and $\left.\mathrm{N}_{2} \mathrm{O}\right)$ are reduced, fertilizers used in production, especially nitrogenous fertilizers, are prevented from contaminating groundwater, soil health is protected, high levels of heavy metals absorbed from the soil and accumulated in the seed under anaerobic conditions are reduced, fertilizer and Plant protection 
products can be applied more effectively and at the same time leakage to the underground is prevented, production can be made in all kinds of soil and topography conditions, it allows polyculture instead of monoculture in the region, in other words, it allows rotation, in regions where climate and water resources are suitable, rice can be produced as a second crop (oat as a front plant: barley, forage peas, vetch, etc.), yield and quality increase with proper technical practices in appropriate varieties, income increases while rice production costs decrease, producer income increases due to polyculture, both irrigation water is saved and demand pressure on water resources is reduced, water resource is limited Production can be made in these regions, production can be made under sufficient washing conditions in regions with low quality water and soil resources, significant production can be made even in periods of severe drought (especially in periods when production cannot be made with pond irrigation), it is not affected by the irrigation water temperature.

As a result of the cost comparison made by considering the production values of Canakkale province, the results in Table 4 have been reached in the evaluation made by examining the positive and negative aspects of the drip irrigation method, which is $20 \%$ more advantageous, and the basin irrigation method. As can be seen from the table, using the drip irrigation method instead of the flood method in paddy production not only saves more than $50 \%$ of water but also significantly reduces costs in many other aspects. In addition to providing a second product opportunity, serious environmental pollution is prevented and a great contribution is made especially to the prevention of mosquito pests.

Table 4. Comparison of Drip Irrigation and Flooded Irrigation Methods in Paddy Production in Canakkale

\begin{tabular}{|c|c|}
\hline $\begin{array}{l}\text { ompared to the } \\
\text { gation water per } \\
\text { igation water to } \\
\text { ond crop before } \\
\text { tool-equipment } \\
\text { planting. } \\
\text { ace labor cost is } \\
\text { vorkforce. } \\
\text { be given until } \\
\text { gation } \\
\text { ands. } \\
\text { eded. } \\
\text { cy in harvest is }\end{array}$ & $\begin{array}{l}\text { Flood Irrigation Method } \\
\left.\text { - Water consumption is high. ( } 15000-24000 \mathrm{~m}^{3} / \mathrm{ha}\right) \\
\text { - The fee paid per decare for irrigation water is high. } \\
\text { - The amount of fuel spent for the irrigation water to } \\
\text { reach the plant root area is high. } \\
\text { - It is not possible to grow pre-crop and second crop } \\
\text { before paddy cultivation. } \\
\text { - Tractor, tool-equipment investment is needed for soil } \\
\text { preparation before planting. } \\
\text { - Sowing is done by iron-wheeled tractors or skilled } \\
\text { workers. } \\
\text { - Fertilization, spraying, etc. maintenance labor cost is } \\
\text { high. A qualified workforce is needed. } \\
\text { - Fertilizers and pesticide/herbicides cannot be given } \\
\text { after a certain period. } \\
\text { - Skilled labor is needed for irrigation. } \\
\text { - Field rent is higher. } \\
\text { - Lands with a very low base and slope are preferred. } \\
\text { - Irrigation equipment investment is not required. } \\
\text { - It is difficult to harvest. There is a need for a crawler } \\
\text { harvester. Work efficiency at harvest is low. } \\
\text { - Paddy yield is lower than drip irrigation. } \\
\text { - Many problems arise in soil properties and fauna. } \\
\text { - It causes mosquito problems. }\end{array}$ \\
\hline
\end{tabular}




\section{Current Trends in Natural Sciences}

Vol. 10, Issue 19, pp. 151-165, 2021

https://doi.org/10.47068/ctns.2021.v10i19.020

Current Trends in Natural Sciences (on-line)

ISSN: 2284-953X

Current Trends in Natural Sciences (CD-Rom)

ISSN: 2284-9521

ISSN-L: 2284-9521

ISSN-L: 2284-9521

\section{REFERENCES}

Adekoya, M.A., Liu, Z., Vered, E., Zhou, L., Kong, D., Qin J., Ma, R., Yu, X., Liu, G., Chen, L., Luo, L. (2014). Agronomic and ecological evaluation on growing water-saving and drought-resistant rice (Oryza sativa L.) through drip Iirrigation. J. Agric. Sci. 6(5), 110-119.

Anonymous (2021a). Web Page. Address: http://ricepedia.org/rice-around-the-world/europe Date of access: 15.02.2021. Anonymous (2021d). PMKSY - micro irrigation drip system in paddy by tmt. j.vijaya rani. I.A.S Additional Director of Agriculture (PM) Department of Agriculture Tamil Nadu. Web Page. Address: https://agricoop.nic.in/sites/default/files/TN-drip_0.ppt. Date of access: 20.02.2021.

Anonymous (2021e). Web Page. Address: https://www.netafim.com/en/crop-knowledge/rice/ Date of access: 20.03.2021.

Anonymous, (2010). National paddy research project reports. Trakya Agricultural Research Institute. Edirne, Turkey.

Anonymous, (2021b). Web Page. Address: https://www.reuters.com/article/climate-change-agriculture/drip-irrigationemerges-to-solve-rice-paddy-problem-idUKKBN28P0ME?edition-redirect=uk. Date of access: 16.02.2021.

Anonymous, (2021c). Web Page. Address: https://www.sustainability-times.com/environmental-protection/dripirrigation-can-reduce-the-vast-footprint-of-rice-cultivation/. Date of access: 18.02.2021.

Arbat, G., Cufí, S., Duran-Ros, M., Pinsach, J., Puig-Bargués, J., Pujol, J., Ramírez de Cartagena, F. (2020). Modeling approaches for determining dripline depth and irrigation frequency of subsurface drip irrigated rice on different soil textures. Water 2020, 12, 1724.

Arbat, G.; Parals, S., Duran-Ros, M., Pujol, J., Puig-Bargués, J., Ramírez de Cartagena, F. (2018). Dinámica del agua en el suelo, productividad del agua y economía en riego por inundación y goteo en arroz; XXXVI Congreso Nacional de Riegos, AERYD: Valladolid, Spain, 2018; Volume 19, pp. 1-10.

Atta, Y.I. (2008). Innovative method for rice irrigation with high potential of water saving. In ICID Congress, integrated water resources management-from concepts to actions. Lahore, Pakistan.

Bansal, R., Sharma, N., Soman, P., Singh, S., Bhardwaj, A.K., Pandiaraj, T., Bhardwaj, R.K. (2018). On-farm drip irrigation in rice for higher productivity and profitability in haryana, india. Int.J.Curr.Microbiol.App.Sci. 7(02), 506-512.

Beser, N., Surek, H., Sahin, S., Kaya, R., Tuna, B., Cakir, R. (2015). Determination of rice (Oryza sativa L.) genotypes suitable for drip irrigation. Bulg. J. Agric. Sci., 21, 1222-1228

Bouman, B.A.M., Xiaoguang, Y., Huaqi, W., Zhiming, W., Junfang, Z., Changgui, W., Bin, C. (2002). Aerobic rice (han dao) a new way of growing rice in water-short areas. Proceedings of the XII. International Soil Conservation Organization Conference, 26-31 May, 2002, Beijing, China. Tsinghua University Press. Pp. 175181

Bouman, B.A.M.; Yang, X.; Wang, H.; Wang, Z.; Zhao, J.; Chen, B. (2006). Performance of aerobic rice varieties under irrigated conditions in North China. Field Crops Res. 2006, 97, 53-65.

Chapagain, A.K., Hoekstra, A.Y. (2010). The green, blue and grey water footprint of rice from both a production and consumption perspective. UNESCO-IHE, Institute Water Education. Value of Water Research Report Series No. 40

De Datta, S. K. (1995) Nitrogen transformations in wetland rice ecosystems. Fertilizer Research 42, $193-203$.

Eid, A.R., Bakry, B.A., Taha, M.H. (2013). Effect of pulse drip irrigation and mulching systems on yield, quality traits and irrigation water use efficiency of soybean under sandy soil conditions. Agric. Sci. 5, 249-261.

FAO (2005) Fertiliser use by crop in Indonesia. Rome: Food and Agriculture Organization.

FAO (2020). FAOSTAT-food and agriculture data. Available online: http://www.fao.org/faostat/en/\#data (accessed on 5 May 2020)

FAO and IFA (2001) Global estimates of gaseous emission of $\mathrm{NH}_{3}, \mathrm{NO}$ and $\mathrm{N}_{2} \mathrm{O}$ from agricultural land. Rome: Food and Agriculture Organization and International Fertilizer Industry Association.

Fawibe, O.O., Hiramatsu, M., Taguchi, Y., Wang, J., Isoda, A. (2020). Grain yield, water-use efficiency, and physiological characteristics of rice cultivars under drip irrigation with plastic-film-mulch, Journal of Crop Improvement, 34 (3), 414-436.

Fillery, I. and Vlek, P. (1982) The significance of denitrification of applied nitrogen in fallow and cropped rice soils under different flooding regimes I. greenhouse experimènts. Plant and Soil 65(2): 153.

Hanson, B.R., May D.M. (2007). The effect of drip line placement on yield and quality of drip-irrigated processing tomatoes. Irrig. Drain. Syst. 21, 109-118.

He, H., Ma, F., Yang, R., Chen, L., Jia, B., Cui, J., Fan, H., Wang, X., Li, L. (2013). Rice performance and water use efficiency under plastic mulching with drip irrigation. PLOS ONE 2013, 8, e83103. 


\section{Current Trends in Natural Sciences}

Vol. 10, Issue 19, pp. 151-165, 2021

https://doi.org/10.47068/ctns.2021.v10i19.020

Current Trends in Natural Sciences (on-line)

ISSN: 2284-953X

Current Trends in Natural Sciences (CD-Rom)

ISSN: 2284-9521

ISSN-L: 2284-9521

ISSN-L: 2284-9521

Kruzhilin, I. P., Dubenok, N.N., Ganiev, M. A., Ovchinnikov, A. S., Melikhov, V. V., Abdou, N. M., Rodin, K. A., Fomin, S. D. (2017). Mode of rice drip irrigation. ARPN Journal of Engineering and Applied Sciences 12 (24), 7118-7123.

Lamm, F.R.; Rogers, D.H. (2017). Longevity and performance of a subsurface drip irrigation system. Trans. ASABE 2017, 60, 931-939.

Li, D.X. (2012). Effect of water-saving irrigation on $\mathrm{CH}_{4}$ emissions from rice fields. In Advanced Materials Research Vol. 396, pp. 1950-1958.

Luo, L., Mei, H., Yu, X., Xia, H., Chen, L., Liu, H., Zhang, A., Xu, K., Wei, H., Liu, G., Wang, F., Liu, Y., Ma, X., Lou, Q., Feng, F., Zhou, L., Chen, S., Yan, M., Liu, Z., Bi, J., Li, T., Li, M. (2019). Water-saving and droughtresistance rice: From the concept to practice and theory. Mol. Breed. 2019, 39.

Maclean, J.L., Dawe, D.C., Hardy, B., Hettel, G.P. (2013). Rice almanac: source book for the most important economic activity on earth. 4th ed.; International Rice Research Institute: Los Baños, Philippines.

Maraseni, T.N., Deo, R.C., Qu, J., Gentle, P., Neupane, P.R. (2018). An international comparison of rice consumption behaviours and greenhouse gas emissions from rice production. J. Clean. Prod. 2018, 172, 2288-2300.

Moran, D., Pratt K. (2010). Greenhouse gas mitigation in land use-measuring economic potential. Grassland carbon sequestration: management, policy and economics. 2010; 11, 197.

Ozer, S. (2018). Determination of plant water consumption components and water-production functions under different irrigation methods in paddy (oryza sativa 1.) farm. Namik Kemal University in Tekirdag Graduate School of Natural and Applied Sciences, Main Science Division of Biosystem Engineering, Ph.D. Thesis.

Parthasarathi, T., Vanitha, K., Mohandass, S., Senthilvel, S., Vered, E. (2015). Effects of impulse drip irrigation systems on physiology of aerobic rice. Indian J. Plant Physiol. 2015, 20, 50-56.

Parthasarathi, T., Vanitha, K., Mohandass, S., Vered, E. (2018). Evaluation of drip irrigation system for water productivity and yield of rice. Agronomy Journal 110 (6), 2378- 2389.

Peng, S.Z., Yang, S.H., Xu, J.Z. (2010). Influence of controlled irrigation on $\mathrm{ch}_{4}$ and $\mathrm{n}_{2} \mathrm{O}$ emissions from paddy fields and subsequent greenhouse effect. Advances in Water Science, 21(2), 235-240.

Rajwade, Y.A., Swain, D.K., Tiwari, K.N., Bhadoria, P.B.S. (2018). Grain yield, water productivity, and soil nitrogen dynamics in drip irrigated rice under varying nitrogen rates. Agron. J. 110 (3), 868- 878.

Ramesh, T., Rathika, S., Ravi, V., Sabarinathan, R., Vered, E. (2019). Drip irrigated paddy: An adaptation strategy to mitigate the climate change. Journal of Pharmacognosy and Phytochemistry 2019; SP2: 190-193.

Rao, K.V.R. (2013). Evaluation of drip irrigation system in paddy crop: A viable alternate to conventional water management practice in paddy cultivation. International Exhibition and Conference on Water Technologies, Environmental Technologies \& Renewable Energy. February 13-14, 2013 Bombay Exhibition Centre, Mumbai, India.

Rekha, B., Jaydeva, H.M., Kombali, G., Geetha, Kumara, A. (2015). Impact of drip fertigation on water use efficiency and economics of aerobic rice. Irrigate Drainage Sys Eng $S, 1,2$.

Sarkar, N., Ghosh, U., Biswas, R.K. (2018). Effect of drip irrigation on yield and water use efficiency of summer rice cultivation in pots. Journal of Pharmacognosy and Phytochemistry, 7(1), 37-40.

Shaibu, Y.A., Banda, H.M., Makwiza, C.N., Malunga, J.C. (2015). Grain yield performance of upland and lowland rice varieties under water saving irrigation through alternate wetting and drying in sandy clay loams of Southern Malawi. Experimental Agriculture, 51(2), 313-326.

Sharda, R., Mahajan, G., Siag, M., Singh, A., Chauhan B.S. (2017). Performance of drip-irrigated dry-seeded rice (oryza sativa 1.) in south asia. Paddy and Water Environment, 15(1), 93-100.

Sharma, N., Bansal, R., Singh, S.N., Singh, B. (2018). A Pragmatical approach on the rice fields demonstrating increase in yield and water saving by using micro irrigation technology. International Journal of Applied Engineering Research 13 (7), 5197-5200. ISSN 0973-4562.

Sharma, V., Singh, Y., Singh, P.K. (2017). Estimation of crop water requirement for summer rice under drip irrigation system in tarai region of uttarakhand. International Journal of Technical Research and Applications. 5 (6) 08-24. e-ISSN: 2320-8163

Singh, T.C., Prajapati, B., Bhardwaj, A.K. (2018). Effect of drip irrigation on growth and yield of direct seeded rice (oryza sativa 1.). IJCS, 6(1), 161-164.

Soman, P. (2012). Drip irrigation and fertigation technology for rice cultivation. Asian Irrigation Forum 2012, 11-13 April 2012, Manila, Philippines. https://events.development.asia/author/p-soman

Taha, E.H. (2020). Fluctuation of nematode populations in some vegetable hosts under drip and conventional irrigation systems. J. of Plant Protection and Pathology, Mansoura Univ., 11 (11), 595-599. 


\section{Current Trends in Natural Sciences}

Vol. 10, Issue 19, pp. 151-165, 2021

https://doi.org/10.47068/ctns.2021.v10i19.020

Current Trends in Natural Sciences (on-line)

Tajane, V., Gulghane, A., Page, A. (2016). Drip and paired row planting for paddy cultivation. $2^{\text {nd }}$ World Irrigation Forum, 6-8 November 2016, Chiang Mai, Thailand.

Tognetti, R., Palladino, M., Minnocci, A., Delfin, S., Alvino, A., (2003). The response of sugar beet to drip and lowpressure sprinkler irrigation in southern Italy. Agric. Water Manage. 60, 135-155.

Topcu, E., Tas, I., 2020. Irrigation water quality for groundwater of canakkale-biga plain. COMU Journal of Agriculture Faculty 2020: 8 (1), 251-260.

Tulucu, K. (2003). Irrigation for special plants. Cukurova Uni. Faculty of Agriculture. Book Publication No = 254, Adana, 75-89 p.

Tuna, B. (2012). Different irrigation applications and water-yield-quality determination of relationship of rice (oryza sativa 1.) cultivation in trakya region. Ph.D. Thesis. Namik Kemal University, Tekirdag.

Voriesi E., Counce, P., Keisling, T. (2002). Comparison of flooded and furrow-irrigated rice on clay. Irrigation Science, 21(3), 139-144.

Wassmann, R., Lantin, R.S., Neue, H.U., Buendia, L.V., Corton, T.M., Lu, Y. (2000). Characterization of methane emissions from rice fields in Asia. III. Mitigation options and future research needs. Nutrient Cycling in Agroecosystems. 2000; 58(1-3), 23-36.

Xing, G. X. and Zhu, Z. L. (2000) An assessment of $\mathrm{N}$ loss from agricultural fields to the environment in China. Nutrient Cycling in Agroecosystems 57(1), 67.

Zia, M.S., Salim, M., Aslam, M., Gill, M.A. (1994). Effect of Low Temperature of Irrigation Water on Rice Growth and Nutrient Uptake. Journal of Agronomy and Crop Science, 173(1), 22-31. 